\title{
Evaluation of the Korean Middle School English Textbook: Listening Skill
}

\author{
Jeong Hanbi \\ English Department, Faculty of Languages and Literature, Petra Christian University, Siwalankerto 121- \\ 131, Surabaya 60236, INDONESIA \\ E-mail: te3441@naver.com
}

\begin{abstract}
This study is done to find out how listening skill is presented in Middle School English 1 textbook published in 2018. In order to answer the research question, the writer used the criteria proposed by Cunningsworth (1995). This is a qualitative research in which the writer evaluated and analyzed by herself. The findings of this study show that listening skill in Middle School English 1 met the criteria proposed by Cunningsworth (1995).
\end{abstract}

Keywords: textbook, textbook evaluation, curriculum

\section{INTRODUCTION}

Textbooks play a crucial role in language learning because they provide various activities, resources, and the materials to be taught; also, the textbooks could be the guideline for teachers (Richards, 2001). Furthermore, it is obvious that textbooks are essential to be used in many language programs (Richards, 2001). For that reason, it is important to select the most suitable textbook for learners. However, textbooks are not always designed perfectly and do not always fit with curriculum or learners' needs. Therefore, textbook evaluation is needed to find out the most suitable textbook for students. According to Cunningsworth (1995, p. 14), coursebook evaluation is also needed "to identify particular strengths and weaknesses in coursebook already in use, so that optimum use can be made of their strong points, whilst their weaker areas can be strengthened through adaptation or substituting material from other books". Through textbook evaluation, a textbook can be used best.

This study aimed to evaluate Middle School English 1, an English textbook which is used for grade 7 in a secondary school in Korean since 2018. By doing this research, the writer hoped that the findings and discussion of this research would give some information to teachers regarding how listening skills presented in Middle school English 1 Korean textbook. As such, the study sought answer to the following question:

1) Does Middle School English 1 meet the cousebook evaluation criteria proposed by Cunningsworth (1995) in terms of listening skill?

Listening is the skill that learners use most in daily lives (Thorn, 2009). However, many EFL students face difficulties in learning listening skill since listening skill receives the least attention in the classroom. Additionally, some factors are needed to be checked for developing listening ability (Thorn, 2009). Here are the seven criteria that Cunningsworth (1995) proposed for listening to help the writer evaluate the listening sections. 
Table 1: Criteria for Evaluating Listening

\begin{tabular}{|l|l|}
\hline Evaluation Criteria & Listening \\
\hline Kinds of material & What kind of listening material is contained in the course? \\
\hline Kinds of activities & $\begin{array}{l}\text { If there are specific listening passages, what kind of activities } \\
\text { are based on them? }\end{array}$ \\
\hline Context & Is the listening material set in a meaningful context? \\
\hline Pre-listening task & Are there pre-listening tasks, questions, etc? \\
\hline Audio material & $\begin{array}{l}\text { What is the recorded material on audio-cassette like in terms } \\
\text { of: sound quality, speed of delivery, accent, and authenticity? }\end{array}$ \\
\hline Video material & Is there any video material for listening? \\
\cline { 2 - 2 } & $\begin{array}{l}\text { If so, is good use made of the visual medium to provide a } \\
\text { meaningful context and show facial expressions, gesture, etc? } \\
\text { [Video material was not accessible to evaluate] }\end{array}$ \\
\hline
\end{tabular}

There are two different ways in listening activities which are general oral activities such as dialogue and role-play and specific listening passages of information. Dialogue and role-play focus on more speaking rather than listening skill. In this case, textbooks would assist learners to develop their listening skill by providing dialogue that has a difficult response (Cunningsworth, 1995). For specific listening passages of information activity, recorded passages are included such as passages for comprehension, passages for seeking information, etc. (Cunningsworth,1995).

Meaningful context is a context that is related to the real world and students (Kaufmann, 2019). Also, meaningful context should be credible, authentic, and rich. According to Kaufmann (2019), it is important to give context that is relevant to learners and makes them to be interested. By his example, Kaufmann has an interest when he listens to Czech material about the history of Czechoslovakia. Therefore, the context about Czech is meaningful for him and willing to listen about them.

Cunningsworth (1995) suggests that recorded listening materials should include pre-listening activities such as include pre-question and preview of listening material in order to hold learners' attention. "Pre-listening activities may pre-teach vocabulary, activate background knowledge, predict content, generate interest in a topic or check ideas and understanding of a topic (Richards and Schmidt, 2010. p.451).

There are several factors that should be checked for recorded materials. First, the sound should be clear enough. Second, the speed of speaking should be different considering learners' ability and level (Cunningsworth, 1995). In general, a normal speech rate in English is around 150-180 words per minute (Allision, 1990, cited in Chang 2009). Third, the accent in listening materials should not digress much from what the learners are familiar with. Furthermore, the speech should be natural like daily life conversation including elision, weak form, and assimilation (Cunningsworth, 1995). Thorn (2009) adds that the listening texts often are scripted and performed by actors in a recording studio so that students have difficulties outside classroom with several reasons such as accents, assimilation, and slang or colloquial expressions. It is important to find the suitable authentic material such as monologues, interviews, and discussion by using real facts and information instead of made-up content (Cunningsworth, 1995, p.141). Additionally, Tomlinson states that 'authentic text (or real world task) involves learners in using language in a way that replicates its use in the real world outside the language classroom' (Tomlinson, 2011, p.ix). 
Recorded materials have limitation that learners cannot see the visual things such as facial expression, gestures, and eye-contact (Cunningsworth, 1995). Therefore, videotapes can be more helpful to understand than recorded materials for learners (Cunningsworth 1995).

\section{METHOD}

In this study, the writer used qualitative approach particularly documentary analysis. A documentary analysis is a qualitative method that uses printed or electronic materials to evaluate and review (Bowen, 2009).

The data for this study was taken from Middle School English 1 textbook. The text book, Middle School English 1, was published by Donga in 2018 under the Korean government's new education policies. The textbook was written by Jang Sung Wook et al and consists of 183 pages, eight units, and one special lesson (Jang et al., 2018). There are eight units and one special lesson. Patterns of activities in each unit are same excluding special lesson. Special lesson does not include listening sections.

The writer applied some steps in order to collect the data and answer the research. First of all, the writer searched textbooks that are used for Korean middle school students. Secondly, the writer chose one Korean middle school English textbook that is popular in $7^{\text {th }}$ grade students in Korea. After the writer chose the English textbook, she read the textbook and read again focusing only on the listening skill sections presented in the textbook. Finally, the writer analyzed the data using table $2 \mathrm{~A}$ and $2 \mathrm{~B}$ below.

Table 2A: Criteria for Evaluating Listening

\begin{tabular}{|l|l|l|l|l|}
\hline Criteria to evaluate & Unit1 & Unit2 & Unit3 & Unit 4 \\
\hline $\begin{array}{l}\text { What kind of listening material is } \\
\text { contained in the course? }\end{array}$ & & & & \\
- Does listening form part of dialogue/ & & & & \\
conversation work? & & & & \\
- Are there specific listening passage? & & & & \\
\hline $\begin{array}{l}\text { If there are specific listening passages, } \\
\text { what kind of activities are based on } \\
\text { them (comprehension questions, } \\
\text { extracting specific information, etc)? }\end{array}$ & & & & \\
\hline 1. . & & & & \\
\hline
\end{tabular}


Table 2B Criteria for Evaluating Listening

\begin{tabular}{|c|c|c|c|c|c|}
\hline Criteria to evaluate & Unit5 & Unit6 & Unit7 & Unit 8 & $\begin{array}{l}\text { Special } \\
\text { lesson }\end{array}$ \\
\hline $\begin{array}{l}\text { 1. What kind of listening } \\
\text { material is contained in the } \\
\text { course? } \\
\text { - Does listening form part of } \\
\text { dialogue/ conversation work? } \\
\text { - Are there specific listening } \\
\text { passage? }\end{array}$ & & & & & \\
\hline $\begin{array}{l}2 . \\
\mathrm{f} \text { there are specific listening } \\
\text { passages, what kind of } \\
\text { activities are based on them } \\
\text { (comprehension questions, } \\
\text { extracting specific } \\
\text { information, etc)? }\end{array}$ & & & & & \\
\hline $3 . \quad \ldots$ & & & & & \\
\hline
\end{tabular}

Notes: Criteria to Evaluate: They refer to the criteria for evaluating textbook as proposed by Cunningsworth (1995).

\section{FINDINGS AND DISCUSSION}

Based on the data, the writer found that the listening skill presented in Middle School English 1 met the criterion proposed by Cunningsworth (1995). Unfortunately, the writer could not analyze the video material since Donga publisher did not provide video materials in their website.

\section{Kinds of Material}

Overall, each unit has both general oral work and specific listening passages excluding special lesson. The special lesson does not provide for listening activities.

The listening skills in Middle school English 1 textbook focus on two different ways which are part of general oral work and specific listening passages. According to Cunningsworth (1995), general oral works focus on more practicing speaking skill rather than listening skills (e.g. role play, dialogues).

\section{Kinds of Activities}

The textbook also includes specific listening passages. The kinds of activities that are provided for specific listening passages are comprehension questions to check the understanding, extraction of information. There are various types of the questions for the activities, which are completion (e.g.p.58, 2), true/false (e.g. p.13, C-1), matching (e.g. p.62,A), ticking(e.g. p.45,C2), drawing (e.g. p.21, Draw and talk), and short answers (e.g.p.29,C-1).

\section{Context}

Overall, all units found in Middle School Englishl have meaningful context since all units are related to students' everyday experience such as school, weekend, and jobs. 
The listening materials in this textbook are presented in meaningful context because listening materials are related to student's everyday experience.

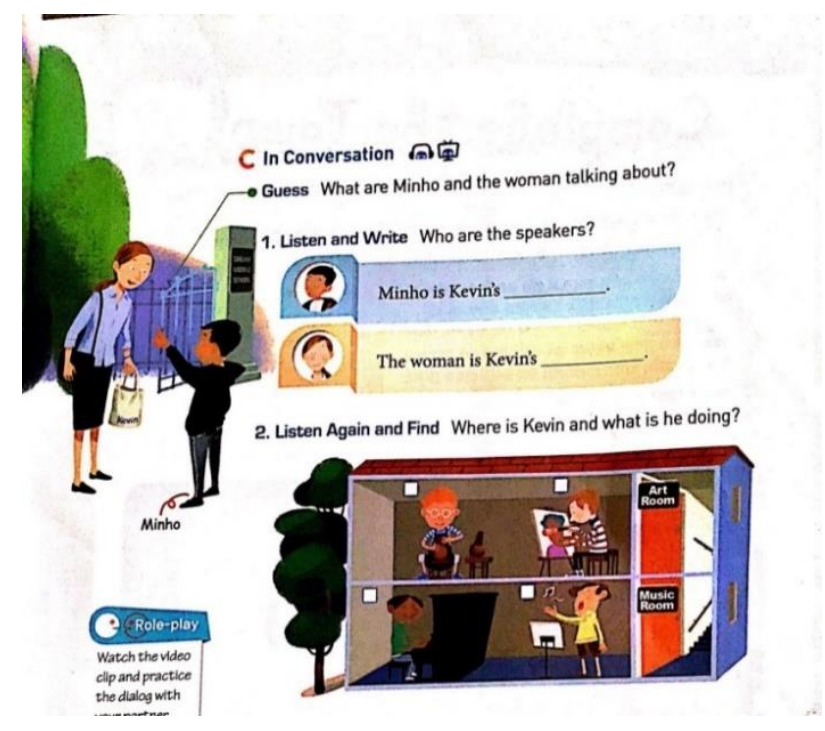

Figure 1

Source: Middle school English 1,2018, p.29

The exercise $\mathrm{C}$ on page 29 presented above is one of examples of meaningful context. There is a conversation between a woman and Minho. Here is a script for the exercise C.

W: Excuse me. Do you know Kevin Baker?

B: Yes, I do. He's my roommate.

W: Oh, good. Where is he? I'm Kevin's mother.

B: He's in the art room. He's painting a picture.

$\mathrm{W}$ : Where's the art room?

B: It's on the second floor.

W: OK. Thanks.

B: You're welcome. Mrs. Baker.

The context is shown that the listening material is related to students' everyday activity by setting a conversation in school. Therefore, it could be considered a meaningful context. The students are familiar with activities in school so that the context can be realistic to students.

\section{Pre-listening Task}

Overall, the textbook includes pre-listening tasks in games and discussion forms that the learners can do before having the main listening task in all units excluding special lesson. Prelistening tasks in Middle School English 1 have a function to get attention from learners.

Each unit has Before you begin sections in discussion form or game. As a pre-listening task, students are asked to discuss related to the topic. The example of pre-listening task in a form of discussion in presented below. 


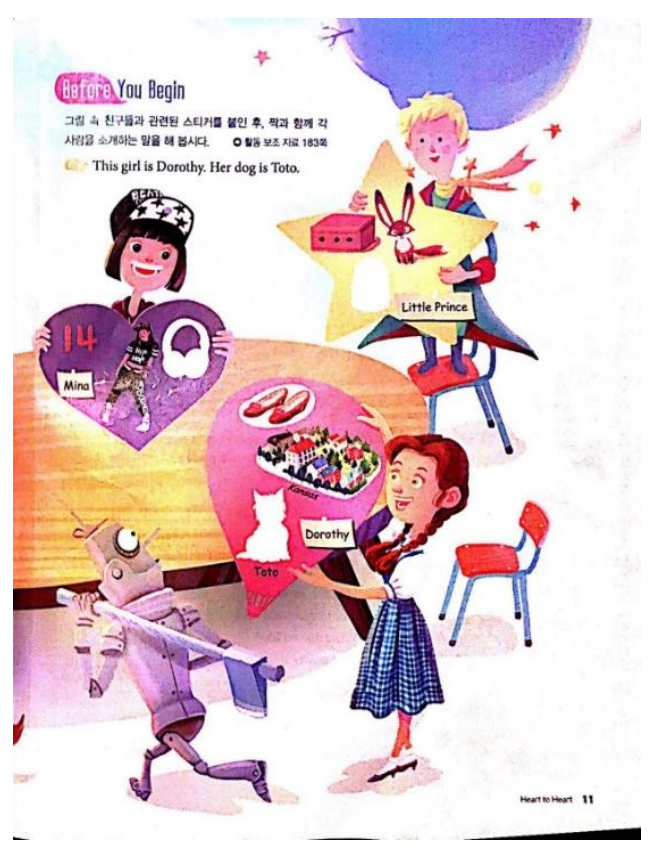

Figure 2

Source: Middle school English 1,2018, p.11

The example of pre-listening task is in a form of discussion that the learners do before the listening task. This unit is the first unit which is about introduction so that students learn how to introduce themselves to others. For pre-listening task in the unit, students are asked to stick a sticker and to discuss who they are. This pre-listening task could be considered as pre-listening task because the pre-listening task is related to subject of this unit which is introduction and provides the activity how to introduce one to others before main listening task. Students can practice or learn sentences through the pre-listening task.

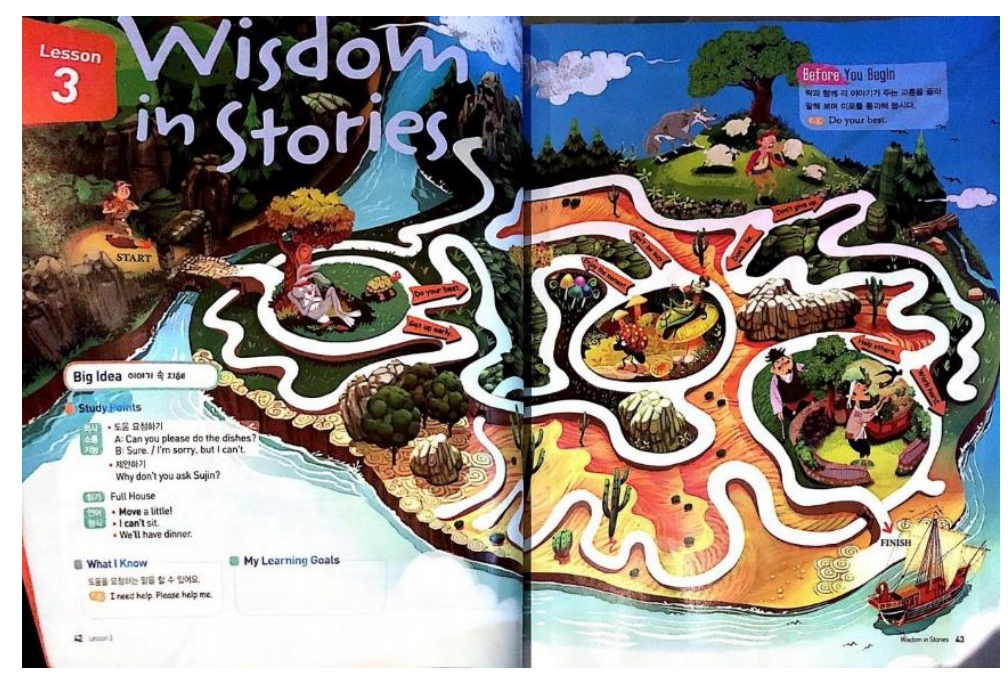

Figure 3

Source: Middle school English 1,2018, p.42-43 
The above example is pre-listening task in a form of discussion and game that the learners do before the listening task. Students are asked to discuss with the partner and to solve mazes by picking out the lessons that each story teaches. This pre-listening task is related to the topic because Unit 3 is about giving an advice and asking for a favor. Through this pre-listening activity, students learn how to give an advice by familiar children stories.

\section{Audio and Video Material}

The Middle School English 1 textbook has both audio and video materials. For video materials, each unit has one animation video. However, the writer could not analyze this part since Donga publisher does not provide video materials in their websites. The audio files are available on the official website of Donga publisher for free. Therefore, in this study, the writer analyzed the audio materials only.

The audio material in terms of the sound quality is very clear. The speed of delivery is approximately 100 words per minute, and the pace is categorized as slow. This seems to be suitable for $7^{\text {th }}$ grade students. The accent being used for recorded material on audio files is mostly inner circle accents especially American accents. This is probably the textbook try to provide good models of pronunciation which is native speakers' accents.

Most of recorded materials are not authentic because listening sections in Middle School English 1 do not have factors such as elision, weak form, and assimilation. Recorded materials are developed for learning and teaching English.

Overall, the recorded material in Middle School English 1 has clear sound quality and artificial materials. It is probably because the students are not advanced in English so that the recorded materials are made for providing good models to learn English.

From the findings the writer found out that Middle School English 1 met the criterion proposed by Cunningsworth (1995).

\section{CONCLUSION}

In conclusion, regarding the listening skill in Middle School English 1, the textbook has both general oral activities and specific listening passages. The listening material set in a meaningful context because the context in listening is related to students' everyday activities. Also, each unit has pre-listening task before main task. The recorded materials are considered slow for speed of delivery and sound quality is very clear. The pace, however, might be suitable for grade 7 students who are not really good at English. However, recorded materials are not authentic and accent is not varied probably because the textbook users' level of proficiency is around pre-intermediate level.

The writer hopes that the findings of this present study would give a contribution to the studies of evaluation of English textbooks and to the government, publishers, and the teachers insights related to the features offered by Middle Schools English 1 in terms of listening skill. Also, she hopes to encourage the teachers to adapt or substitute the material. She also recommends that a further study would be conducted regarding teachers' and students' opinions after using the textbooks. It would be interesting to see what the teachers and students thought about the textbook. 


\section{REFERENCES}

Bowen, G. A. (2009). Document analysis as a qualitative research method. Qualitative Research Journal, 9(2), 27-40. doi:10.3316/QRJ0902027

Chang, A.C.S. (2009). The Effect of Reading While Listening to Audiobooks: Listening Fluency and Vocabulary Gain. Asian Journal of English Language Teaching 21, 43-64.

Cunningsworth, A. (1995). Choosing your coursebook. Oxford: Heinemann Publishers Ltd. Jang, S.W., Jin, S.I., Kang, E.K., Yoon, J.M., Lee, H.K., Paul S.G., .. Yeom, M.S., (2018). Middle school English 1. Seoul: Donga

Kaufmann. S (2019). Your Language Resources Should be Meaningful. Retrieved from https://blog.thelinguist.com/language-resources

Richards, J. C. (2001). The role of textbooks in a language program. Cambridge: Cambridge University Press.

Thorn, S. (2009). Mining Listening Texts. Modern English Teacher, 18 (2), pp.5-13.

Tomlinson, B. (2011). Materials development in language teaching $\left(2^{\text {nd }}\right.$ ed.). Cambridge: Cambridge University Press. 